\title{
The Landscape of Languages at the Commencement of the 21st Century
}

\author{
Seong-do Kim \\ Korea University
}

\begin{abstract}
The purpose of this paper is to make a graphic description of the present situation of languages in the world. Even though it is estimated that the number of languages that exist in the world range from 3,000 to 6,000 we do not have sufficiently adequate data for the number of languages in the world. We made some hypothesis on the number of world languages in the past and present. By examining the number of languages that have become extinct, we can conclude that there existed more languages in the past as compared to the actual number of languages. Our conclusion is that only about 400 languages will survive in the world in the near future.

Furthermore, by reviewing the number of major language users in the world languages, this paper claims that the study of the landscape of language in the world will help understand language and its nature better.
\end{abstract}

\section{Introduction}

The number of languages that exist in the world ranges from 3,000 to 6,000. Despite the advancement of Anthropology and Linguistics, we still lack sufficient data on the number of languages in the world. There may be many reasons for this. However, one of the reasons that is easy to perceive is that only a small number of the languages that exist in the world have an inherent writing system. More specifically, out of all the languages 
that exist in the world, only 100 languages have their own writing systems. Languages that are only spoken vary on a wider range compared to those in written form. As a result, it became difficult to distinguish language from their dialects. Obviously, it is simple to differentiate between a language and a dialect theoretically. A dialect is a regional variant from of a language; dialects are mutually intelligible within the same language. However, this concept of mutual intelligibility is in reality difficult to define. For instance, two languages used by two different tribes seem closely related to each other from a linguist's point of view even though one tribe cannot understand the language of the other tribe. Another example is that when Spanish is spoken very slowly to them, Italians claim that they understand the language.

However, no one claims that Spanish is a dialect of Italian. Ultimately, the yardstick for distinguishing a language from a dialect seems to be based on political economic, national factors of the country where the language is spoken rather than on the components of a language versus those of a dialect. In sum, it is impossible to begin to comprehensively portray the landscape of language at the end of the 21th century. Thus, I will only be making a graphic description of the present situation of languages in the world.

\section{The Landscape of Language in Continents}

The continental distribution of languages is as follows:

1) North America (down to the Rio Grande): In North America, there are about 260 million speakers of English and about 5 million speakers of French. Also, 250,000 American Indians speak 50 different Indian local dialects.

2) Latin America and the West Indies: In Latin America and the West Indies, the dominant languages are Spanish and Portuguese. 
There are about 150 million speakers of Spanish and about 140 million Brazilian speakers of Portuguese in that part of the world. However, the number of English speakers is increasing in Jamaica and the West Indies. Also more than 7 million French speakers exist in Haiti, the West Indies of French influence and Guiana.

3) Europe: In Europe there are 30 officially recognized languages; almost the same number of languages are not official languages. Among them are Basque and Breton. Other such unofficial languages can be found in the Caucasus regions.

4) Asia: There are about 30 different official languages and about 600 unofficial languages in Asia. Among the unofficial languages, 200 languages exist in Indonesia and Russia each, about 70 in the Philippines, and around 30 in Burma.

5) Oceania: Many languages exist in Malaysia and Australia. About 100 languages were investigated in the New Hebrides and the Republic of Vanuatu. It was reported that 500 languages were found in Papua New Guinea. Since studies of such languages are still at the primitive stage, these languages could be in reality just dialects. Anyhow, there are at least 700 languages in this part of the world.

6) Africa: One of the representative tribes, the Bantu language family extends from Cameroon to Kenya. About 800 languages belong to this language family, but many of them are fading away due to syntactic similarities of these languages. More than 500 languages exist around West Africa, Senegal and Sudan. More than half of these languages are spoken by Nigerians with the highest population in the area. It can be pointed out that countries of less developed regions have higher numbers of languages. Tribes of Australia, Papua New Guinea and those near tropical forests use languages spoken by only hundreds or thousands of people. On the other hand, developed countries with political authorities and various system of education have formed unity in language. In order 
to do this, they have utilized political authorities and various other systems to sacrifice ethnic languages of individual countries.

\section{The Number of Major Language Users of the World}

At the end of the 20th century, the number of languages used by more than one million people is estimated to be only about 100 . About 30 languages exist in America, about three to five of them in Africa, about 50 to 55 in Asia, and about 28 in Europe.

Speakers of languages such as Gaelic, Irish, Breton, Basque, etc. amount to be less than a million. Users of these fervently desire to preserve their culture; thus, these languages have stronger possibility of surviving rate than other similar languages. On the other hand, there are many languages spoken by more than a million people; yet, they are on the verge of fading away due to their being irresistible to the major language used in the country. Some of the languages used in China and Indonesia fall under this category. Many languages do not have any resisting power to sustain pressures coming from the dominant local culture. For example, natives of Australia or in the Amazon areas have their language and existence threatened. Similarly, the languages of minority ethnic groups in Africa are being threatened by more powerful African languages.

Major languages of the world used by more than 100 million speakers are estimated to be about 12 as shown below:

$\begin{array}{llll} & \begin{array}{l}\text { Native } \\ \text { Language }\end{array} & \begin{array}{l}\text { Second } \\ \text { Language }\end{array} & \text { TOTAL } \\ \text { Chinese } & 800,000,000 & 200,000,000 & 1,000,000,000 \\ \text { English } & 350,000,000 & 250,000,000 & 600,000,000 \\ \text { Hindi } & 350,000,000 & 250,000,000 & 600,000,000\end{array}$




$\begin{array}{llll}\text { Spanish } & 315,000,000 & 15,000,000 & 330,000,000 \\ \text { Russian } & 165,000,000 & 120,000,000 & 285,000,000 \\ \text { Indonesian-Malasian } & 50,000,000 & 140,000,000 & 190,000,000 \\ & & & \\ \text { Portuguese } & 160,000,000 & 20,000,000 & 180,000,000 \\ \text { Arabic } & 140,000,000 & 30,000,000 & 170,000,000 \\ \text { Bangladeshi } & 170,000,000 & 60,000,000 & 170,000,000 \\ \text { Franch } & 75,000,000 & & 135,000,000 \\ \text { Japanese } & 125,000,000 & - & 125,000,000 \\ \text { German } & 90,000,000 & 10,000,000 & 100,000,000\end{array}$

About 100 languages are spoken by a large part of the world population, i.e., by 450 million, and the remaining 2,900 languages are spoken by the rest of the world population, close to 4,000 million people. In the latter case, the average number of people per language amounts to about 100,000. If we consider languages spoken also as a second language, we will get an even larger number. All languages are in a hierarchical reation to one another. In addition, different languages get mingled into one another as time passes.

\section{Hypothesis on the Number of World Languages Past and Present}

The earth is about 5,000 million years old. The advent of life forms is about five hundred million years ago. The advent of the Neanderthal men goes back about two million years ago. According to the theory of scholars of this field, the advent of natural languages goes back to only about some 10,000 years ago. Based on the findings it shows that 3,000 languages existing in the world are the result of evolution for a long period of time. Then, is it possible to portray the landscape of languages of the past? It is possible to reconstruct languages that are no longer in use. Many languages 
have disappeared that were in use in the past. Many languages have changed so drastically as compared to their earlier forms. Most modem languages of the world used today have lost their primitive forms and changed so much over thousands of years that it is almost impossible to reconstruct their proto-forms. Hence, it is very difficult to answer such questions as "Are we able to reconstruct the proto-forms of Indo-European languages?!" "What is the origin of the Korean language?", etc.

By examining the number of languages that have become extinct, we can conclude that there existed many more languages in the world in the past as compared to the number of languages today. This assumption can be tested indirectly. If we examine the language situations in Australia or New Guinea, about one language is spoken by a thousand people on the average. Then, in the prehistoric period if we assume that about three million people existed on the earth, it can be estimated that about three thousand languages existed during that period of time.

Despite the increase of population in the world due to medical and scientific development in the last one hundred years, the number of languages has decreased. Then, by sharing information worldwide the entire world will turn out to be like the developed countries discussed previously with ten million people per language. We can conclude that only about 400 languages will survive in the world in the near future.

\section{Man and Language}

Linguistic achievements of today help us understand language and its structure. We now have a better understanding of the development of language and its proto-type. We can summarize such observations as follows: 
-Children are born with a brain that enables them to acquire a language.

-Acquiring the first language is similar to programming a computer. Our brain is programmed according to a language.

-We utilize some part of the brain to acquire a language.

-Language is a tool that expresses our thoughts and emotions.

-With other tools of human functioning, language has been applied to the needs of men.

-Language cannot express everything, and thus our understanding of language cannot be competed.

\section{Conclusion: Disappearing Languages}

Many former languages of the world disappeared due to various reasons. The language of a certain culture or country disappears when the language of a conquering nation takes over, e.g., the conquest of Carthage of Rome. Very rarely does the opposite case may occur. It is pity that not many studies have been conducted on so many languages, for instance the languages of the New Guineas and those in the Amazon River, disappearing from the earth. Maybe, we should write a song in memory of these dead languages.

\section{References}

Yaguello, M. 1981. Alice au Pays du Language : pour Comprendre la Linguistique. Paris, Le Seuil.

Crystol, D. 1981. Cambridge Encyclopedia of Language. Cambridge, Cambridge University Press. 
Kloss, H. et G.D. Mc Connell. 1974. Composition Linguistique des Nations du Monde( 5 vol., par Continent; l'Afrique est Absente). èd. le Centre international de recherche sur le bilinguisme, Quebec, Presses de l' Universite de Laval.

Kloss, H. et G.D. Mc Connell. 1974. Composition Linguistique des Nations du Monde (voir Generalites sur les Langues, au Debut de la Bibliographic). èd le Centre international de recherche sur le bilinguisme, Quebec, Presses de l'Universite de Laval.

Chaudenson, F. 1992. Des iles, de Hommes, des Langues. ed. Fernand Nathan, Paris.

Rey, A. 1982. "Encyclopèdies et Dictionnaires", coll, 《Que Sais-je?》n ${ }^{\circ}$ 2000. Paris, PUF.

Breton, R. 1976. “Gèographie des Langues,” coll, 《Que Sais-je? 》 nº 1648. Paris, PUF.

Jean, G. 1987. "L, Ècirture, Mèmoire des Hommes." coll. 《Dècouvertes》 èd. Gallimard, Paris.

Kristeva, J. 1970. Le Langage, cet Inconnu、 Paris, SGPP.

Ouvrange Collectif. Le Mythe de la Langue Universelle. ouvrage collectif, Paris, èd. de Minuit, 1979.

Yaguello, M. 1974. Les Fous du Langage : des Langues Imaginaires et de Leurs Inventeurs. Paris, Le Seuil.

Ouvrage Collectif sous la Direction de Jean Perrot. Les Langues dans le Monde Ancien et Moderne (Actualisation du Prècèdent Ouvrage). èd. du CNRS, 2 vol, parus :

I . Les Langues de l'Afrique subsaharienne - Pidgins et Crèoles, Paris, 1981.

II. Langues chamito-sèmitique, Paris, 1989.

Ouvrage Collectif sous la Direction d'Antonie Meillet. 1952. Les langues du 
nxonde. è. du CNRS, Paris ; rèd. Slatkine, Paris, 1981, 2 vol.

Whorf, B. L. 1971. Linguistique et Anthropologie. èd. Denoël et Gonthier,Paris.

Meillet, A. 1965. Linguistique Historiques et Linguistique Gènèrale. èd. H. Champion, Paris. 